\title{
A program for audit of infections and antibiotic resistance in critical ill
}

\author{
HS-I Hanberger ${ }^{*}$, G Fransson, S Walther \\ From International Conference on Prevention \& Infection Control (ICPIC 2011) \\ Geneva, Switzerland. 29 June - 2 July 2011
}

\section{Introduction / objectives}

Infections caused by antibiotic resistant pathogens is a growing concern that complicates treatment and influences patient outcome in critical ill. The purpose of this work was to develop and test the feasibility of a system for continuous audit of resistance and compliance to antibiotic treatment guidelines for severe infections in critical care.

\section{Methods}

Records from ICU patients (including i.e. reason of admission, illness severity score, interventions and nursing workload, adverse events, outcome in the ICU) were collected in the Swedish Intensive Care Registry (SIR). Mortality data was added weekly for each episode of care (EOC). A web service was developed for individual collection of results from microbiological cultures and analyses for each EOC. Development of the web service included a detailed and cumbersome translation of laboratory specific nomenclatures for samples, cultures, microbials and methods.

\section{Results}

Bacteriological data from clinical microbiological laboratories were merged with its respective EOC in SIR yielding data on patient-specific bacteriology and microbial susceptibility. Trends in microbial resistance among alert pathogens were examined. Data on gender, age, co-morbidity were collected from SIR and correlated to microbiological findings and 30-day mortality. Resistance patterns were analyzed to assess the appropriateness of National guidelines for the treatment of pneumonia in the ICU showing $86 \%$ possible accuracy with suggested treatment for community acquired and $82 \%$ for hospital acquired disease.

Infectious Diseases, Clinical experimental medicine, Linköping, Sweden

\section{Conclusion}

Microbial findings matched with reason of ICU admission can be used to validate or update national guidelines for proper antibiotic treatment. This program may be developed to an early warning system for antibiotic resistance in intensive care

\section{Disclosure of interest}

None declared.

Published: 29 June 2011

\section{doi:10.1186/1753-6561-5-S6-O6}

Cite this article as: Hanberger et al: A program for audit of infections and antibiotic resistance in critical ill. BMC Proceedings 2011 5(Suppl 6): O6.
Submit your next manuscript to BioMed Central and take full advantage of:

- Convenient online submission

- Thorough peer review

- No space constraints or color figure charges

- Immediate publication on acceptance

- Inclusion in PubMed, CAS, Scopus and Google Scholar

- Research which is freely available for redistribution
() Biomed Central

\section{Biomed Central}

